


\title{
O Rei Nebkauré Kheiti
}

\section{Autor(es): $\quad$ Canhão, Telo Ferreira}

Publicado por: Centro de História da Universidade de Lisboa

URL persistente:

URI:http://hdl.handle.net/10316.2/23713

DOI:

DOI:http://dx.doi.org/10.14195/0871-9527_20_2

Accessed : $\quad$ 26-Apr-2023 13:05:48

A navegação consulta e descarregamento dos títulos inseridos nas Bibliotecas Digitais UC Digitalis, UC Pombalina e UC Impactum, pressupõem a aceitação plena e sem reservas dos Termos e Condições de Uso destas Bibliotecas Digitais, disponíveis em https://digitalis.uc.pt/pt-pt/termos.

Conforme exposto nos referidos Termos e Condições de Uso, o descarregamento de títulos de acesso restrito requer uma licença válida de autorização devendo o utilizador aceder ao(s) documento(s) a partir de um endereço de IP da instituição detentora da supramencionada licença.

Ao utilizador é apenas permitido o descarregamento para uso pessoal, pelo que o emprego do(s) título(s) descarregado(s) para outro fim, designadamente comercial, carece de autorização do respetivo autor ou editor da obra.

Na medida em que todas as obras da UC Digitalis se encontram protegidas pelo Código do Direito de Autor e Direitos Conexos e demais legislação aplicável, toda a cópia, parcial ou total, deste documento, nos casos em que é legalmente admitida, deverá conter ou fazer-se acompanhar por este aviso.

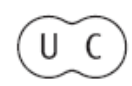




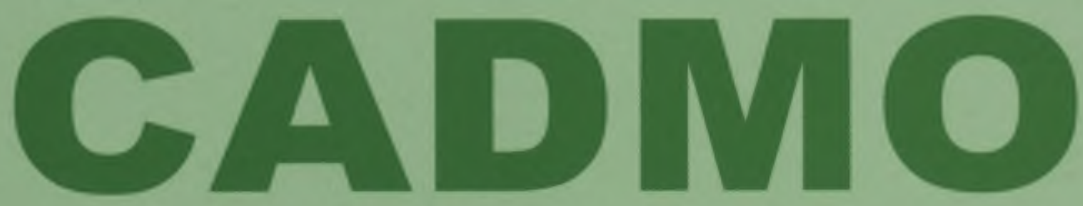

Revista de História Antiga

\author{
Centro de História \\ da Universidade de Lisboa
}

\title{
20
}

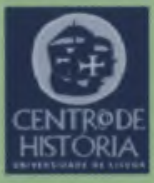

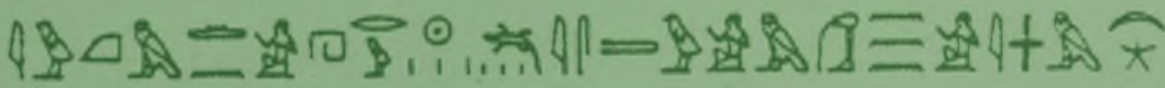



MHNIN AEI $\Delta$ E $\Theta E A ~ \Pi H \Lambda H I A \triangle E \Omega$ 


\title{
O REI NEBKAURÉ KHETI(1)
}

\author{
TELO FERREIRA CANHÃO \\ Universidade de Lisboa \\ telofcanhao@gmail.com
}

\section{Resumo}

Depois da apresentação dos principais meios de distinção entre o rei e os outros homens e da crença na sua divinização, analisam-se as intervenções da terceira personagem do Conto do Camponês Eloquente, o rei Nebkauré Kheti, vinculando através dela outro conjunto de ideias que consubstanciam o conceito de maat, agora vista na sua dimensão cósmica e na sua relação com o Estado faraónico.

Palavras-chave: dimensão cósmica de maat; solidariedade comunicativa; solidariedade social; institucionalização de maat.

\section{Abstract}

After presenting the most important ways to distinguish between the king and the other men as well as his deification, we will analyse the interventions of the third character in The Tale of The Eloquent Peasant, king Nebkaure Kheti, conveying through it a set of ideas that substantiate the concept of maat, now seen in its cosmic dimension and in its relation with pharaonic State.

Keywords: cosmic dimension of maat, communicative solidarity; social solidarity; institutionalization of maat. 
A estrutura ideológica do mundo concebido pelos Egípcios antigos assentava em sistemas cosmogónicos que atribuíam a criação a um demiurgo ou a um colégio divino, a partir da qual se constituiu um universo harmonioso onde todos os elementos eram indissociáveis e onde o politeísmo existente não excluía "a consciência da unidade do divino"(2). Para os Egípcios, a ideia de totalidade consubstancia a de perfeição. Como se sabe, o papel do rei era o de mediador entre o demiurgo e os homens, concentrando em si funções de carácter divino e laico, sem paralelo em qualquer modelo conhecido no mundo ocidental. Filho dos deuses e responsável pela ordem e equilíbrio no mundo, todos os súbditos o reconheciam como fonte da felicidade e da riqueza, bem como seu protector por excelência. Por isso adoravam-no, veneravam-no e glorificavam-no, fazendo-o surgir nos templos e santuários, representado a par dos deuses ou esmagando com a sua força invencível os inimigos.

Através das insígnias reais mostrava-se um homem diferente de todos os outros e tornava visível a sua essência divina, não permitindo que ninguém esquecesse essa diferença. Dos principais símbolos da realeza destacam-se as coroas: a hedjet, họt ( ), a coroa branca do Alto Egipto; a decheret, dšrt ( $/$ ) a coroa vermelha do Baixo Egipto; a sekhemti, shmty ${ }^{(3)}(\sqrt[H]{)})$ "as Duas Poderosas", com a junção da coroa do Norte e a do Sul, e que exprime a união da deusa Uadjit w3dyt ( $\mathcal{L}_{\text {) }}$ ), colocada na coroa vermelha do Norte, com a deusa abutre Nekhbet $n h b t\left({ }^{-}\right)$, presente na coroa branca do Sul; o kheprech, hprš $(\emptyset)$ a coroa azul (só surge no fim do Império Médio); atef, 3tf (fol), a coroa real osiríaca; chuti, šwty $(\bigsqcup)$ ), a coroa com plumas de Amon (as duas últimas de uso post mortem). O rei usava ainda o nemés (forma grega que corresponde ao egípcio nemsit), $n m s$ ( $\hat{f}$ ), um pano listado que Ihe cobria a cabeça e caía sobre os ombros.

Destacam-se também os ceptros: hekat, hk st ( ( ), um símbolo do poder que provavelmente alude ao passado pastoril; nekhakha, nhish $(\bigwedge)$, possivelmente alude ao passado agrícola sendo semelhante a um mangual, podendo representar ainda um flagelo(4), antes do mais associado a Osíris e, provavelmente, simbolizando a justiça; uase, w3s ( $(\{$ ), que simboliza a luta entre Set e Apopi na Duat, dando a quem a possuísse poder sobre as forças tenebrosas. 
Por sua vez, a serpente sagrada iaret (representação ofídica da deusa Uadjit), que por via helenística assume a designação latinizada de uraeus, era amiúde usada pelo rei sobre a testa(5), quer integrada numa coroa quer mesmo num diadema, simbolizando o olho abrasador de Ré, e bastava por si só para identificar a realeza. Durante a vigência da XXV dinastia, de origem núbia, os reis usaram duas serpentes sagradas atestando a união do Egipto com a Núbia. A serpente sagrada iaret era também usada em conjunto com a cabeça de um abutre, a aludir à deusa Nekhbet, numa demonstração do usual dualismo egípcio, como símbolo da união entre Alto e Baixo Egipto.

De referir, também, a "falsa barba», clafet, klaft, que o faraó só usava em cerimónias oficiais ou que aparecia em representações pintadas ou esculpidas, como símbolo do seu estatuto divino e da sua imortalidade. Semelhante à barba de Osíris, tinha a particularidade de ser por vezes trapezoidal, ondulada e direita, enquanto a do deus da eternidade se apresentava curva na ponta inferior. Acrescente-se ainda o saiote real chendjit (šndyt), com a cauda de touro pendente atrás da cintura, um costume ancestral que simbolizava a sua grande virilidade, a pele de pantera que usava em cerimónias religiosas, e as sandálias que, não sendo propriamente uma insígnia, também eram distintivas, ou outros símbolos de realeza que surgem com menos frequência em textos ou na iconografia. Note-se que as sandálias reais tinham por vezes desenhadas imagens de asiáticos ou de pretos que o soberano ia calcando à medida que caminhava, esmagando assim, em cada passada, os inimigos do Egipto.

Outra forma de distinção do faraó em relação aos restantes humanos era a titulatura real. De uma forma geral, no Egipto antigo, para além de representar a própria identidade de cada um, o nome era sobretudo a expressão da própria existência, realçando não só as qualidades da pessoa, mas referindo-se mesmo à ocupação profissional do seu portador. Era ainda um elemento fundamental de sobrevivência, possuindo uma dimensão orgânica como o corpo, o ba ou o ka. Apagar um nome era negar o indivíduo e condená-lo ao esquecimento. As pessoas comuns tinham normalmente dois ou três nomes: o nome maior ( $r n$ 3), dado à nascença, que produzia $\circ \operatorname{ser}^{(6)} \mathrm{e}$, mais tarde, em qualquer altura da vida, podia ser-lhe atribuído indiferentemente um de dois nomes ou mesmo os dois, o bom nome ( $r n n f r)$ ou o pequeno nome ( $r n n d s)$, uma espécie de diminutivo. Todos tinham ainda o nome secreto ( $\left.r n s^{\prime} t^{3}\right)$ que, de facto, era o principal. Dado pela mãe à 
nascença, só esta o conhecia, podendo transmiti-lo ou não, ao filho. Era aquele que revelaria o verdadeiro indivíduo e que, em caso de algum problema que destruísse total ou parcialmente a sua identidade revelada, garantiria a memória que lhe permitiria alcançar a eternidade ${ }^{(7)}$.

Para melhor se distinguir dos outros homens, o faraó tinha mais nomes. A titulatura completa compunha-se de cinco nomes ou títulos, que só se tornaram usuais a partir do início do Império Médio, embora alguns desses nomes já viessem do Império Antigo ou mesmo da Época Pré-Dinástica. A sua forma e conteúdo constituem um autêntico protocolo. O primeiro, pelo qual os reis eram conhecidos, na generalidade, até à IV dinastia, era o nome de Hórus $(h r)$, que mostrava o rei como incarnação do deus Hórus. Inscrevia-se dentro de um serekh (srhh), a estilização de um palácio real encimado, normalmente, por um falcão(8). O segundo, o nome das Duas Senhoras (nbty), invocava a protecção das deusas tutelares do Alto e do Baixo Egipto Uadjit e Nekhbet, já antes referidas. O terceiro, o nome de Hórus de Ouro (hr nbw), representava simultaneamente a vitória de Hórus sobre o vil Set e a solarização do deus vitorioso, portanto, do faraó. O quarto, o nome de coroação ( $n s w$-bit), era antecedido pela expressão $n s w$-bit, um junco e uma abelha ( + ( ) (lit.: "o do junco" e "o da abelha»), sendo o mais importante de todos. Era o primeiro nome do rei, o seu nome solar, aquele que dava existência institucional ao faraó e onde, sobretudo, se revia o programa de governo. O quinto, o nome de nascimento ( $s^{r} r$ ), atribuído pela mãe ao filho acabado de nascer, era sempre precedido pela designação «filho de Ré» (?゚)

Os quatro primeiros nomes constituiam o nome verdadeiro ( $\left.r n \mathrm{~m}_{3} \mathrm{r}\right)$ porque, no seu conjunto, evocavam as funções que o rei assumia com a sagração, sendo-ihe atribuídos na coroação. Marcam o programa do reinado de cada rei, sendo por isso, de facto, um protocolo que, além do mais, dá destaque à estrutura da titulatura real: $4+1$. Isto é, quatro nomes de função atribuídos na sagração real e um nome de homem adquirido à nascença, numa clara distinção entre o homem institucional e o homem físico. Os três primeiros nomes definem a natureza real e constituem-se em autêntica teologia do poder. Os dois últimos aparecem envoltos em cartelas, mnš ou šnw, derivado do verbo šn $(i)$, "rodear", que representam um espaço fechado por uma corda com as pontas presas num nó, simbolizando que tudo aquilo que o sol rodeia é o universo que pertence ao faraó(9). 
Após a coroação do faraó a titulatura real raramente voltava a ser citada completa, destacando-se como mais frequentes o nome de Hórus, o nome de coroação e o nome de nascimento, sendo sobretudo através dos dois últimos, especialmente do último, que hoje conhecemos os nomes reais a partir da IV dinastia. Além dos cinco nomes canónicos, os reis dispunham ainda de diversos epítetos, para valorizar determinadas facetas, como são os casos, por exemplo, de "Aquele que conquista todos os países com a sua força vigorosa", "Aquele que faz viver a verdade e destrói a mentira" ou "O Nilo do Egipto que inunda o país com a sua perfeição" ${ }^{(10)}$. Sem nada exprimirem da sua personalidade, mostravam no entanto o que se esperava do monarca.

Se a titulatura identificava o faraó e o seu programa de governo, ela também o legitimava como incarnação de Hórus e filho do deus solar Ré. Na ideologia faraónica, mito e história estiveram sempre ligados. A partir da concepção da criação segundo um modelo antropomórfico concebe-se a identificação divina do faraó, inclusive com Osíris através de Hórus e do percurso solar nocturno, sendo o rei morto também adorado sob a forma solar. Outro processo de assegurar a origem divina do faraó era através da predestinação real, isto é, pela crença na sagração antes mesmo de sair do ventre da mãe. Não só assegurava o acesso ao trono dos filhos reais por via paterna, como dava relevo ao papel da rainha transmissora do sangue divino e real. Deste modo ligava-se a Hathor, deusa do amor e da maternidade, simbolizada por uma vaca ou por uma figura antropomórfica com oreIhas de vaca num rosto humano, evocando assim o mito da criação conhecido por "Mito da Vaca do Céu», que associa um texto a uma ilustração do mesmo animal como representação do céu, sob o qual se encontra o Sol na sua barca. Em alguns casos, legitimou a posteriori o acesso ao trono de forma menos usual, como a concepção divina de Hatchepsut, a única mulher que se assumiu como faraó, ou legitimou mesmo usurpações, como o caso de Tutmés IV, que num sonho à sombra da Esfinge viu aparecer-lhe o deus Horemakhet (hrr-m-3hth, "Hórus no horizonte", que personificava o Sol nascente) que o predestinou a rei, legitimando a própria eliminação dos irmãos. Não obstante, estas são apenas algumas filiações divinas do faraó, já que foram numerosas ao longo da história do Egipto antigo.

Ainda assim, no plano das instituições, havia que criar condições ao rei para que, em circunstância alguma, fosse confundido com outro homem, sobretudo ao nível dos dignitários (vizires, governadores, chefes 
sacerdotais ou militares...). Essa legitimação era conferida por duas cerimónias exclusivas da realeza: a cerimónia da sagração e o jubileu real. Independentemente da sucessão se processar por parentesco ou por conquista do poder, o ritual de inauguração de um novo reinado era a sagração do rei, também apelidada de coroação ou entronização, que visava "aumentar a personalidade do rei e transformá-la» (11), sendo por isso considerada um conjunto de rituais de passagem de uma condição a outra, em que um homem se transformava num ser com qualidades inacessíveis aos outros humanos. Embora na prática se tratasse de uma série de actos iniciáticos solitários, apenas respeitantes ao rei e ao deus, realizados estritamente no círculo das pessoas necessárias à sua execução, a coroação era considerada um acto colectivo. Cerimonial dirigido pelos sacerdotes, compunha-se dos ritos de despertar do novo rei e saída do palácio (um despertar simbólico e mágico dirigido pelos sacerdotes), de purificação (dois sacerdotes vestidos de Hórus e de Tot purificavam o novo rei, primeiro com água e depois unguentos), de entrada do rei no templo (espaço sagrado) acompanhado por Montu (deus nacional da guerra, de origem tebana, que se apresentava com cabeça de falcão e características guerreiras, transmitindo ao rei protecção, poder, vitória e invencibilidade), de imposição das coroas por Hórus e Set (dois sacerdotes incarnavam os deuses representando as Duas Terras), de elevação real (no contexto tebano, o rei era enquadrado por dois deuses, normalmente Montu e Atum, que o conduziam até Amon), de alimentação do novo rei (absorção fictícia de leite de uma deusa simbolizando a sua passagem de comum mortal a monarca eleito pelos deuses), de entronização e de proclamação dos nomes de reinado que o novo soberano assumia. Depois o soberano percorria um circuito à volta do palácio, numa representação simbólica do seu poder sobre todo o Egipto. Em suma, o cerimonial conferia poder terrestre ao novo Hórus e poder institucional ao monarca.

Se a entronização decorria, sobretudo, entre os deuses, o jubileu real desenrolava-se, principalmente, num mundo humano, visando essencialmente regenerar o poder real. Era constituído por um conjunto de cerimónias a que os Egípcios chamavam "festa Sed» (ḥb-sd) e representavam pelo hieróglifo thntst ( do poder real simultaneamente no Alto e no Baixo Egipto. Na origem e durante muitos reinados foi tutelado por Ptah de Mênfis. Por isso era uma festa realizada em Mênfis e o seu carácter nacional deslocava grande número de súbditos de todo o Egipto. Através de um amplo 
conjunto de rituais mágicos aplicados enquanto ser físico, procurava-se regenerar e revitalizar simultaneamente o poder do faraó e a instituição real. Numa das cerimónias o rei prestava homenagem à totalidade dos deuses agrupados segundo a sua origem geográfica, numa clara oposição entre o Norte e o Sul, manifestação do tradicional dualismo da cultura egípcia. Noutra encenava uma espécie de simulacro em que triunfava sobre a velhice e a morte, ao renascer entre cânticos e danças. Este renascimento, para além de ser referenciado ritualmente aos quatro pontos cardeais de diversas maneiras, uma delas atirando quatro flechas em direcção às quatro orientações, estendia-se a todo o país com a renovação da estatuária, o levantamento de obeliscos, a construção de santuários e o fabrico de cerâmica comemorativa que se enchia de oferendas, depois destinadas a alimentar a multidão atraída pelos festejos. Algumas fases da coroação eram repetidas parcialmente, agora num ambiente de renovação e não de entronização, como o caso da imposição das coroas e da purificação do rei.

Embora se conheçam excepções, celebrava-se pela primeira vez em qualquer dia de um mês não determinado, do ano em que o monarca cumpria 30 anos de reinado. Podia coincidir com o dia e o mês de coroação real ou marcar, simplesmente, um acontecimento importante do ponto de vista cósmico. Obrigatoriamente participavam a família real, sacerdotes, altos dignitários, músicos e dançarinos, a que se juntava grande número de populares. Depois de celebrado pela primeira vez não havia regra fixa para os seguintes, que podiam até ser anuais. No seu longo reinado de 66 anos, Ramsés II celebrou treze Heb-sed, $h b$-sd.

Esta perenidade da criação que evidencia que o rei não é o demiurgo mas apenas o seu herdeiro, existência que apesar das capacidades sobrenaturais não exclui a sua humanidade, paira na atmosfera de alguns papiros do Primeiro Período Intermediário e do Império Médio que apresentam a monarquia como factor fundamental para a vida dos homens, pondo a tónica no seu carácter político. Isso é visível no Ensinamento de Merikaré, testamento de um rei heracleopolitano ao filho, datado da VIII dinastia, e no Ensinamento de Amenemhat I ao seu filho Senuseret. O primeiro texto é exemplar pela visão racional, humanista e responsável que dá da monarquia ${ }^{(12)}$.

Contudo, a monarquia egípcia fundamentava-se na visão cosmogónica do mundo, que dependia do cumprimento da maat. $\mathrm{E}$ o único ser que na terra podia dialogar com a divindade era o rei. Por isso, manter a necessária ordem e harmonia entre os homens pertencia à 
sua responsabilidade que, diariamente, ao romper do sol, o levava a cumprir os rituais concernentes a essa finalidade, oferecendo simbolicamente aos deuses o único alimento de que necessitavam: Maat. No quotidiano, a permanência desta divindade entre os homens, pode ser vista como uma "moralidade "natural"» que travava o exercício arbitrário do poder, sobrepondo-se a qualquer tipo de controlo das instituições criadas pelos homens ${ }^{(13)}$. Verdadeiro suporte do poder, isto é, do Estado, do qual era indissociável, concentrava no rei todas as suas vertentes: social, ética e cósmica. Por isso, quando morria um monarca era necessário coroar o seu sucessor o mais rápido possível, porque a inexistência de rei traduzia grande perigo, uma vez que suspensos os rituais do único oficiante legítimo para prestar culto a Maat ${ }^{(14)}$, não era possível manter a paz, a ordem, o equilíbrio, a justiça, a solidariedade social e cósmica entre os homens.

As duas referências no Conto do Camponês Eloquente a um monarca, surgem em B1, 104 e B2, 131: Nebkauré (nb-k3w-r). Como referimos, trata-se, provavelmente, de Nebkauré Kheti, um dos últimos reis das dinastias heracleopolitanas, cujo nome de coroação significa "Os Espíritos de Ré são o Senhor" ou "Os Espíritos de Ré são Dourados»(15). Para além de integrarem a acção no Primeiro Período Intermediário, rodeiam-se da parte da narrativa que caracteriza a figura do faraó e apresentam-nos a sua relação com os súbditos e com a justiça. De novo se vê que o artifício literário necessário ao desenvolvimento e conclusão do processo ideológico, surge como processo intencional. Nesta óptica, no Primeiro Período Intermediário e no Império Médio, sobretudo neste último, no que respeita aos reis reformadores não devem ter existido muitos períodos de aborrecimento para o rei ${ }^{(16)}$. Pelo menos não é essa a leitura que o conto suscita. O comportamento do soberano (B1, 109-111) parte de premissas correctas. A justiça no Egipto, por natureza demorada, obrigava a lavrar actas das queixas e de inquéritos às partes envolvidas, para posterior análise dos juízes. Nas sessões onde se proferiam as sentenças procedia-se do mesmo modo. O monarca era o primeiro dos juízes e só intervinha em situações excepcionais ${ }^{(17)}$. Esta, justamente, foi transformada numa situação excepcional. Não pela gravidade do crime, mas pela inverosimilhança da situação: um elemento do grupo social mais ignorante comporta-se como um erudito. É o palco perfeito para explanar o ideário. O camponês fala bem? Então criem-se as condições ideais para tirar o maior partido do fenómeno: mantém-se o silêncio sem lhe responder para que continue a falar e dá-se-lhe cerveja em excesso para 
que solte a língua. É um estratagema literário para criar espaço à exposição seguinte e não uma forma ardilosa para combater o aborrecimento.

Em abono, ainda, desta visão interpretativa, em B1, 109-110, quando o rei afirma «Se tu desejas ver-me de boa saúde, tu deves trazê-lo aqui sem responder a nada do que ele possa dizer", nada leva a supor tratar-se de qualquer questão de aborrecimento! "Se tu desejas ver-me de boa saúde" significa "se me queres agradar" ou, numa fórmula mais popular, "se queres ser meu amigo", expressão vulgarizada que qualquer pessoa com um mínimo de intimidade diz a outra quando pretende um favor seu. É evidente que há aqui, indiscutivelmente, uma relação entre um superior e um subalterno, mas isso está em segundo plano, sustentado pela firmeza do pedido e pela forma como é executado. E em B2, 131-132, ainda a expressão «E isto foi mais agradável ao seu coração [do rei] do que todas as coisas deste país inteiro", refere-se ao acto de deferência que o inferior hierárquico acabara de realizar. Ao dar os papiros ao rei, Rensi reconhecera a sua superioridade, como a pessoa mais habilitada a julgar entre os presentes. Ainda que se reconheça já ter morrido!

No final do seu nome aparece a expressão "justo de voz" ou «justificado" ( $\left.m 3^{c}-h r w\right)$, epíteto que acompanhava sempre os reis mortos depois de atingirem a eternidade na passagem pelo tribunal de Osíris, após ter sido aceite como correcta $(m 3)$ a sua declaração de inocência $(h r w)$. Esta expressão representava para os Egípcios muito mais do que a simples companhia do defunto. Encontramos-Ihe significação ao nível da vida terrena do indivíduo, da imortalidade no Além, da vida cósmica e do Estado faraónico. A «VOZ" tanto se pode referir ao juiz que profere uma sentença de "justo", como ao defunto que proclama a sua inocência através da confissão negativa, considerada "justa». Em qualquer dos casos trata-se de um julgamento onde ressalta a dicotomia entre justo e injusto, inocente e culpado ou, simplesmente, entre o sim e o não. É a oposição entre bem e mal, na qual os culpados são injustos e os inocentes, justos. Ora, como só estando em conformidade com maat se pode ser justo, só com ela se triunfará sobre os adversários. E como aquele que vence é poderoso, «justificar" é triunfar. De qualquer modo, é um triunfo que só na esfera religiosa tem sentido, tornando o indivíduo totalmente dependente de maat, mas que, apesar disso, elimina a hipótese de vingança pessoal, uma vez que só depois do tribunal se pronunciar será possível agir contra o vencido. No tribunal divino do julgamento dos mortos, o 
defunto confronta-se com a própria deusa Maat. Ao nível meramente religioso, a pena de avestruz, mais do que enfrentar o coração, salva-o de todas as confrontações possíveis ${ }^{(18)}$.

Recorrendo à imagem geométrica proposta por Assmann, o significado da justificação desenvolve-se na esfera humana em três campos circulares concêntricos. O mais interior e pequeno é o da vida terrestre, onde a justificação depende fundamentalmente da solidariedade social para o êxito da felicidade dos homens. O segundo, que envolve 0 anterior, é o da sobrevivência após a morte antes de alcançar a eternidade, que retém os que escaparam ao primeiro julgamento. $A$ instância de julgamento é ainda a sociedade, sendo ela quem permitirá ou não a sobrevivência póstuma na terra. O mais largo de todos é o da imortalidade no Além, onde o defunto preservará toda a sua identidade e viverá transformado em deus vivo. Nenhum campo desvaloriza os outros, desenvolvendo-se entre eles o princípio de continuidade e estando todos dependentes da mesma maat, que sobre eles actua sempre com as mesmas regras ${ }^{(19)}$.

No plano cósmico, a "justificação do deus" parte do triunfo do sol sobre as trevas, e este triunfo é o grande símbolo da maat. Assumindo-se como força cósmica preexistente que simboliza a luz/o bem/ /a justiça/a verdade/a ordem na luta eterna contra isefet, que representa as trevas/o mal/a injustiça/a mentira/a desordem, triunfa todas as manhãs fazendo-se luz, depois de guiar a barca solar no percurso solar nocturno e de se opor a Apopis e a outras forças maléficas que habitam a Duat e praticam inúmeros actos hostis a quem pretende atravessar as suas diversas regiões. É a concepção dualista, tão usual na cultura egípcia, concretizada no périplo solar, exemplo de sucesso permanente reportado à "primeira vez". Ressalve-se, no entanto, a diferença entre cosmogonia primordial e cosmogonia perpétua, já que a primeira deve ser entendida como acto criador e a segunda como acto de triunfo e de justificação. Esta oposição é apresentada através de fórmulas jurídicas, em que a divindade é "justificada» e o inimigo "punido", constituindo o espelho da realidade terrestre, onde o rei assume o papel de Ré. O simbolismo da encenação cósmica é claramente político, fazendo o paralelismo entre os dramas do Sol no céu e no inferno e do rei na terra ${ }^{(20)}$.

Se realizando maat se triunfava na vida e na morte, então era necessário unir Maat a Ré. Essa união, para além de poder concretizar-se pelo abraço permanente da deusa ao deus, podia ser também obtida pela deusa dando de comer e de beber a Ré, que assim vivia 
de Maat. Através desta ideia do criador de Maat necessitar dela própria para viver, se define o conceito egípcio de oferenda: devolução a Deus daquilo que ele dá(21). E como é aqui que se enquadra o ritual do culto diário, também este princípio foi devidamente inserido na trama do Conto do Camponês Eloquente: "Age para com aquele que age, para fazer com que ele aja" (B1, 140-141). O resultado surge a seguir: "Isto é agradecer a alguém por aquilo que ele faz". Eis o princípio da reciprocidade. Neste culto tinha lugar também a recitação de textos através dos quais se fazia "subir Maat", isto é, a sua incarnação em palavras alimentava o deus para que ele pudesse continuar a actuar positivamente. Entramos na teoria da linguagem ${ }^{(22)}$. Criada por Ré através do seu movimento e brilho, esta linguagem em forma de luz e tempo era escutada e interpretada pelo rei, que a fazia depois ouvir pela divindade devolvendo-a sob a forma de discurso, gerando através desta colaboração uma autêntica solidariedade universal entre os homens e os deuses. E era a permanente marcha do percurso solar, acompanhado pela ininterrupta e perfeita recitação, que mantinha esta solidariedade. Este discurso cultual não só analisava os acontecimentos cósmicos, como numa acção "pré-formativa" produzia a realidade expressa, proporcionando uma comunicação entre o homem e o cosmos que, ao pretender inteirar a divindade da situação na terra, tornava difícil distinguir o cósmico do social, uma vez que passavam a ser o reflexo um do outro «interpretando-se e organizando-se mutuamente»(23).

A dependência dos Egípcios em relação a Maat torna-se mais óbvia através da sua concepção de Estado, idealizada no Império Antigo, na V dinastia, como instituição cuja existência visava apenas realizar Maat. Só depois tinham lugar todas as outras competências e obrigações, igualmente abrangidas pelo poder da deusa. Como se disse, o demiurgo instalou o rei na terra com a obrigação de realizar Maat. Através de rituais conhecidos desde o Império Antigo, o rei, único ser qualificado para essa finalidade, de pé ou ajoelhado, com um braço estendido saudava diariamente o sol no momento do seu nascimento com a "oferta de Maat", uma pequena estatueta que representava a deusa sentada com a habitual pena de avestruz na cabeça e o "corpo envolto num vestido colante", que tinha nas «mãos escondidas pela roupa o símbolo da vida: redundância da sua própria imagem que já personifica o princípio vital do qual se alimenta o deus", enquanto mantinha o outro braço levantado em gesto de adoração, ao que juntava uma "recitação pré-formativa» (24). E ao fazê-lo 
aniquilava as forças contrárias, personificadas por Isefet, mantendo a ordem e a harmonia. O dualismo cósmico, por um lado prefigura a justiça, o já enunciado julgamento entre forças opostas, por outro, o facto de ser recitada, apresenta-se como meio de comunicação entre os homens e Ré.

Uma vez que o silêncio e a ausência de resposta eram características da não-existência, esta resposta diária aos deuses era fundamental para se manter "o diálogo vivo, ininterrupto entre deus e o homem, dividido entre duas polaridades opostas representadas pelo amor e pelo medo" ${ }^{(25)}$. Segundo a tradição, no templo de Amon era recitado pelo oficiante dos rituais diários a quem o faraó delegara esse poder, como "fórmula para a oferenda de Maat", o seguinte hino: "Maat veio para estar perto de ti, Maat está presente em todo o lugar onde tu vás de tal modo que tu estás provido de Maat [...] a roupa que cobre os teus membros é Maat [...] o sopro das tuas narinas é Maat [...] o teu pão é Maat, a tua cerveja é Maat...»(26).

Esta tarefa fazia do soberano o primeiro dos funcionários: existia na terra para cumprir uma função claramente definida, respondendo por ela directamente ao demiurgo. A sua actuação devia ser exercida em conformidade com Maat. É, de facto, uma cadeia de causalidade, em que Ré dá origem ao rei, que por sua vez origina Maat, origem da ordem social na terra. Portanto, o Estado, através do culto diário exercido pelo monarca que fazia recair o poder de Maat sobre a humanidade, e da própria figura do chefe de Estado, a quem a essência divina obrigava a obedecer, era o pilar que satisfazia os deuses no céu e sustentava a paz, a ordem e a harmonia entre os homens. De forma concisa e clara: Maat era a razão de ser do Estado no Egipto antigo ${ }^{(27)}$. Em complemento e de igual importância, a actividade construtora do rei media a eficácia religiosa do reino, servindo apenas secundariamente como motivo de glória pessoal do monarca. Por isso erguiam monumentos, talhavam estátuas, muitas em fino ouro do deserto ou na mais bela pedra, ou restauravam e acrescentavam santuários existentes ${ }^{(28)}$.

Apesar de tudo, dedicado a Maat, pilar da cultura egípcia cuja figura encheu templos e túmulos, só foi possível identificar um único templo. Situado no recinto norte de Karnak, junto ao templo de Montu, ergue-se um pequeno e singelo templo, bem visível e identificado nas plantas do grande santuário inseridas na obra de Wilkinson e no atlas de Baines e Málek ${ }^{(29)}$. Mas o que se sabe ao certo sobre o mesmo nada tem a ver com a sua história religiosa, porque terá sido, sim- 
plesmente, uma sala de tribunal onde foram julgados alguns ladrões de túmulos reais no Império Novo, ignorando-se se posteriormente foi mantida como templo. Parece não haver qualquer outra edificação que se possa associar à deusa e, de facto, «nem era preciso - 0 verdadeiro templo de Maet é o coração de cada homem „(30).

A própria actividade de combatente do faraó tinha fundamento cosmogónico, não só em virtude da situação pouco privilegiada do homem na criação, mas também devido ao reconhecimento do papel de destaque dos Egípcios face ao resto da humanidade e à consciencialização de que ao combate só o rei dava "sentido e eficácia assegurando a bela ordem universal", isto é, conseguindo a paz ${ }^{(31)}$. Independentemente do processo criativo, os Egípcios entendiam o homem como uma das espécies entre as que tinham sido criadas na "primeira vez". Contudo, a sua posição evoluiu e tornou-o distinto dos outros. Primeiro, por ser o único a praticar a agricultura e depois como fonte de inspiração para a construção do pensamento teológico, uma vez que as principais características divinas são as dos homens. Depois disso, um hino a Aton, de Amen-hotep IV-Akhenaton, fala da criação das raças que se organizaram em quatro, tal como os pontos cardeais, assumindo a ideia de totalidade da humanidade: Egípcios, Asiáticos, Núbios e Líbios. Tendo sido todas criadas pelo demiurgo egípcio, seriam submissas ao faraó, o seu representante na terra. Mas como os Egípcios tinham sido os primeiros a aparecer, eram os únicos com direito a usar a designação de "homens", num mundo que os deuses caracterizaram como "o Egipto e o exterior» ${ }^{(32)}$. Daqui resulta a ideia de que todos os que não eram Egípcios eram inimigos.

Para combater, quer nas guerras defensivas, quer nas ofensivas, ou mesmo nas civis, autênticas visões apocalípticas do fim do mundo, a intervenção da humanidade processava-se sempre no sentido de propiciar o retorno à paz da «primeira vez». E a única personagem capaz de os conduzir era o faraó. Dispunha de imensa força física e energia anímica para combater com eficácia forças nefastas, animais ou homens, sobretudo inimigos do Egipto. Através de uma educação desportiva extremamente atlética onde a caça tinha papel de destaque, com vista à criação de um ser que não conhecia obstáculos e cuja flecha jamais errava o alvo, o rei assumia forças e poderes animais, estranhas ao comum dos mortais. Não só a força do touro ou do leão e a visão do falcão eram corporizadas por inteiro, como se relacionavam partes do seu corpo, como os braços, os dedos, os olhos ou a cabeça, com partes de animais, relevando determinadas 
capacidades desses animais, como a pujança das patas ou dos cornos do touro, ou o poder das garras ou dos rugidos dos felinos. Uma das mais poderosas metamorfoses assumidas pelo rei era, possivelmente, a do grifo. Este animal mítico resume "cada um dos animais da criação, onde o rei capta uma característica particular à qual se assimila de seguida, numa arquitectura intelectual que o homem elaborou para exprimir que no seu corpo se aloja a totalidade dos outros seres vivos e respectivas potencialidades»(33).

Devido a todos estes poderes, a eficácia real na guerra era total. São os próprios monumentos e textos comemorativos que nos mostram o faraó a derrotar sozinho exércitos inteiros desbaratados em desordem sob as patas dos cavalos atrelados ao seu carro, rodeado de pilhas de cadáveres ou de mãos cortadas, normalmente estimados com o recurso a grandezas imprecisas e avultadas, como centenas de milhar ou de milhões. São sempre cenas onde ordem e caos se opõem. De um lado, um mundo ordenado onde o rei, firme no seu carro, assume uma posição frontal ocupando normalmente a maior parte do espaço da cena, geralmente sozinho ou seguido por fileiras organizadas de soldados, a quem a desordem do resto da composição em nada ameaça. Do outro, a confusão e desordem de um exército massacrado que recua perante a eficácia do soberano. Como a caça exercita a guerra, a mesma desordem aparece em cenas de caça, onde o exército inimigo é substituído por chusmas de animais. Estas imagens, acompanhadas ou não de ritos, assumiam através da magia a função de reforço do Estado, com o objectivo de neutralizar as investidas do inimigo, depreendendo-se, assim, que o domínio do caos só é vencido através de uma luta constante. É a ideia de retorno à "primeira vez" para manutenção da ordem e da paz demiúrgicas, que se deviam reflectir entre os homens, que na terra prolongam os combates divinos dos mitos da criação. Portanto, também através da função de combatente do rei, a razão de ser do Estado egípcio era Maat $^{(34)}$.

E como o homem comum não dispunha de capacidade para realizar e garantir a maat, dependia do Estado, a instituição que o fazia. $\mathrm{O}$ dualismo era garantido na terra através da presença de isefet, que representava o caos para o qual resvalavam permanentemente os homens, através da injustiça, da mentira, da violência, da desordem e da lei do mais forte ${ }^{(35)}$. Por isso surge a necessidade permanente de Maat, única que se the podia opor, dependendo a habitabilidade do mundo da sua vitória sobre isefet, para defesa dos mais fracos. Uma 
tal capacidade só a possuía o Estado e as instituições a quem delegava poderes, numa missão que consistia em libertar o homem de si próprio quando escravizado pelos piores instintos. Esta constitui a mais alta razão de existência do Estado na concepção egípcia: o demiurgo criou um mundo de igualdade, mas os valores inatos do homem como a avareza e o egoísmo põem-no em perigo. Têm que ser completamente vencidos para que se implante a solidariedade.

Daqui decorre a importância fundamental da ordem faraónica que, por depender de uma força superior para a qual não foram concebidos processos auto-reguladores, é sempre posta em causa quando falha "a solidariedade entre o céu e a terra", seguindo o processo cósmico o caminho de isefet, que o lança no caos. Surgem então as lamentações e o desejo de que um novo rei reponha a maat e a ordem seja restabelecida ${ }^{(36)}$. Foi o exacto percurso do Egipto no período em que teria decorrido a acção do Conto do Camponês Eloquente: o declínio do Império Antigo e o surgimento do Império Médio, separados pelo penoso Primeiro Período Intermediário. Como afirma Assmann: «A instituição faraónica é portanto mais uma religião do que um Estado: porque a libertação de energias cosmogónicas e salvadoras faz-se por adoração e por troca comunicativa. O Estado é a gestão da salvação. É a união perfeita da salvação e da dominação " (37).

Torna-se claro, então, que "solidariedade" e "comunicação" são noções comuns a todas as esferas de maat, cujo epicentro é "a categoria social da solidariedade comunicativa ${ }^{(38)}$. O processo inicia-se na relação do rei com os deuses, não sendo de maneira alguma um exclusivo real. O monarca solicita a protecção divina através de uma acção em que devolve à divindade o que ela própria criara, sendo então reconhecido como amado da divindade que, em troca da solidariedade que aquele the manifesta, o premeia com amor. Não é uma questão pessoal, mas o reconhecimento da dependência da humanidade em relação ao mundo divino. Através do rei, "Maat estabelece as ligações que ligam o mundo humano aos deuses e assegura a integração universal»(39). Depois, na sociedade, Maat estabelece os elos que ligam os homens uns aos outros e asseguram a sua integração social. Portanto, Maat é "o princípio sociológico da solidariedade, estendido às dimensões políticas da empresa faraónica e às dimensões cósmicas do regime solar»(40).

A perfeita integração do rei nestes princípios é visível nas duas intervenções reais do Conto do Camponês Eloquente. Na primeira, nas frases $\mathrm{B} 1,112-116$, o rei assegura o sustento não só de Khuenanupu 
durante a sua retenção, como o da família, considerando as necessidades por que estariam a passar. É uma intervenção clara de solidariedade social emitida pela mais alta figura do Estado, o «filho de Ré", aquele que ao receber a protecção divina tem obrigação de proceder do mesmo modo na terra entre os homens, devendo ser o primeiro a dar o exemplo através de uma conduta indiscutivelmente orientada pelos princípios de maat. A distribuição de cereais é, na prática, sinónimo do comportamento correcto e, metaforicamente, sustentáculo da própria prestação da justiça. Mas esse exemplo torna-se brilhante em B1, 114-115, quando, no mais elevado sentido ético, o soberano completa a sua acção com a "ordem" de Rensi não revelar quem lhe fornecia o sustento. Por um lado, afasta qualquer hipótese de suborno, pois sem se conhecer o doador das vitualhas, não se esperariam contrapartidas. É, provavelmente, mais uma alusão crítica à corrupção que se pretendia erradicar. Por outro, ilustra o sentido de Estado à luz do ideário de maat: dar sem esperar retribuição porque o auxílio aos mais necessitados, aos mais fracos, era a sua obrigação. Em qualquer dos casos os alimentos foram fornecidos em quantidades excessivas. No que se refere à cerveja e pão do camponês já foi dada uma justificação; no caso da família é possível que o soberano tenha agido com certa prodigalidade para contrabalançar o facto de reter aquele que, aparentemente, representava o sustento da família. É também um exemplo que o conto pretende veicular.

$\mathrm{Na}$ segunda intervenção, em B2, 130-133, a questão que se levanta é outra. É igualmente um exemplo de comunicação de solidariedade social levada a cabo pelo monarca, mas, enquanto a anterior abre caminho ao desenrolar da ideologia, esta põe-lhe um ponto final. O «manual» fecha-se envolto em apurada ética. Reconhecendo o trabalho e a integridade de Rensi, e através dele de todos os funcionários não corrompidos ou subornados, o rei recompensa-o à luz do princípio da reciprocidade: permitindo-lhe reposicionar a sua posição perante Khuenanupu e julgar o crime em sua substituição. É também uma prova de solidariedade institucional.

Finalmente, refira-se que quando se alude a elevação ética, é evidente que se trata de algo que ultrapassa os limites de um simples comportamento. Isto tem a ver também com o homem interior, com a sua mentalidade e a sua vontade ${ }^{(41)}$. A própria abundância demonstrada pelo monarca ao fornecer alimentos em quantidades excessivas, opunha-se à avareza que o faraó devia evitar, mostrando que a solidariedade institucional era também maat como altruísmo prescritivo. 
O faraó apenas cumpria maat. Assim, compreende-se por que razão a monarquia divina faraónica nunca representou, de facto, um poder ditatorial! Embora possamos parafrasear Luís XIV - “L'État, c'est Maat" ${ }^{(42)}$ - o princípio de maat e a concepção de Estado faraónico afastam quaisquer ideias absolutistas, descaracterizando a hipotética afirmação do «iluminado" monarca. Grosso modo, a diferença encontra-se sobretudo na prática, já que do ponto de vista teórico, seguindo os princípios estabelecidos por J. B. Bossuet nos finais do século XVII ${ }^{(43)}$, ambos são sagrados porque provêm de Deus, paternais porque os monarcas são os "pais" do povo, absolutos porque não dependem de ninguém para além da divindade. Devem ainda exercer um poder que não arbitrário, assegurando a ordem contra a anarquia e submetendo-se à razão, entendida como sabedoria, percepção superior das coisas, de modo a tornar o povo feliz. Até a frase "o rei está no palácio, o leme está na tua mão e o mal está instalado à tua volta» (B1, 158-159) reflecte a ideia de que o rei ocupa o lugar que Ihe compete e onde é insubstituível; no lugar que os deuses lhe determinaram para que cumprisse a sua missão entre os homens, mantendo a paz, a ordem, o equilíbrio, a justiça e a solidariedade social e cósmica. Mas não deveremos esquecer que a divindade faraónica incarnava num homem, o que era, provavelmente, a única fraqueza da sua existência.

A faceta humana do rei aparece principalmente nos contos, nem todos do género do Conto do Camponês Eloquente, onde o papel do rei se centra sobretudo na manutenção da ordem e defesa dos pobres, mas chegando a ser observado segundo perspectivas mais prosaicas, denunciando os mais escandalosos comportamentos, como é o caso do Conto do Rei Neferkaré e do General Sisené, onde um rei, possiveimente Pepi II, é observado pelo "primeiro detective amador» que a história regista, que segue o rei numa série de visitas, aparentemente de carácter amoroso, a casa do general(44). Quando porventura se aplicam as palavras "deus" ou "divino" ao soberano egípcio, não é uma referência ao ser físico mas ao carácter sagrado da sua função. Ele seria mais um "rei-sacerdote» do que um "rei-deus» (45), uma vez que a sua prática deriva do compromisso religioso assumido perante os deuses, em cuja vontade se dissolve a sua acção individual(46). De facto, o faraó era um homem que por vezes era atravessado pela palavra divina, o que, mesmo assim, marcava uma grande diferença em relação ao comum dos mortais. 


\section{Notas}

(1) Este texto tem como referência o conto publicado no número dezasseis desta revista: T. F. CANHÃO, "O Conto do Camponês Eloquente", em Cadmo 16 (2006), 11-54. Sobre esta temática ver ainda: T. F. CANHÃO, "O Conto do Camponês Eloquente na Literatura do Antigo Egipto", em Cadmo 14 (2004), 125-143; T. F. CANHÃO, "Datação e Temática do Conto do Camponês Eloquente", em Cadmo 15 (2005), 163-187; T. F. CANHÃO, "Khuenanupu, um camponês eloquente", em Cadmo 17 (2007), 81-112; T. F. CANHÃO, "O grande intendente Rensi», em Cadmo 19 (2009), 65-96.

(2) M.-A. BONHĖmE e A. FORgeAu, Pharaon. Les Secrets du Pouvoir, Paris: Armand Colin Éditeur, 1988, p. 128.

(3) A palavra egípcia shmty ( poderosas", por tradição e via grega aparece usualmente antecedida de um artigo definido, p'-shmty, donde surge a habitual designação de pchent.

(4) Frequentemente vê-se confundido flabellum com flagellum. O primeiro serviria para afastar as moscas e o segundo para executar castigos de chicotadas.

(5) Na XXV dinastia os faraós núbios usaram dois uraeus para assinalarem que eram ao mesmo tempo reis do Egipto e de Kush.

(6) M. H. T. LOPES, "A problemática da nomeação no Antigo Egipto", em Revista da Faculdade de Ciências Sociais e Humanas, 9 (1996), Lisboa, Ed. Colibri, pp. 11-12. Refira-se que o contrário, a ausência de nome, constituía ausência de memória social e a condenação ao anonimato impedia a vida eterna. No caso dos faraós a situação era ainda mais grave, porque a damnatio memoriae, ou seja, a martelagem do seu nome nos monumentos, tinha como efeito a negação da sua própria existência e o seu esquecimento (M.A. BONHĖME e A. FORGEAU, Pharaon. Les Secrets du Pouvoir, p. 34 ; M. H. T. LOPES, "A problemática da nomeação no Antigo Egipto", em Revista da Faculdade de Ciências Sociais e Humanas, 9 (1996), pp. 14-15).

(7) Cfr. M. H. T. LOPES, "A problemática da nomeação no Antigo Egipto", em Revista da Faculdade de Ciências Sociais e Humanas, 9 (1996), pp. 11-15.

(8) Há casos em que Hórus foi substituído pelo animal Set ou aparecem em simultâneo Hórus e Set (P. A. CLAYTON, Chronicle of the Pharaohs, Londres: Thames and Hudson, 1994, p. 218).

(9) Cfr. idem, ibidem; cfr. M.-A. BONHÈME e A. FORGEAU, Pharaon. Les Secrets du Pouvoir, pp. 34-37.

(10) E. HORNUNG, "O Rei», em S. Donadoni (dir.), O Homem Egipcio, Lisboa: Editorial Presença, 1994, p. 241.

(11) M.-A. BONHĖME e A. FORGEAU, Pharaon. Les Secrets du Pouvoir, p. 267.

(12) M. LICHTHEIM, Ancient Egyptian Literature, vol. I - The Old and Middle Kingdoms, Berkeley, Los Angeles, Londres: University of California Press, 1975, pp. 97-109 e 135-139; W. K. SIMPSON (ed.), The Literature of Ancient Egypt, New Haven, Londres: Yale University Press, 1973, pp. 180-197; B. G. TRIGGER, B. L. KEMP, D. O'OCONNOR e D. LLOYD, Historia del Egipto Antiguo, Barcelona, Crítica, 1997, p. 101.

(13) Idem, p. 102. É evidente que este restabelecimento da "primeira vez" tinha em vista a manutenção da ordem e da harmonia, permanentemente postas em causa pelas forças do caos, sempre prontas a instalar-se. 
(14) A protecção e auxílio das divindades só podiam ser garantidos se fosse possível evitar o caos e para evitar focos de destabilização era necessário espalhar por todo o Egipto lugares de culto, mantidos pelas permanentes oferendas e doações. O soberano não podia oficiar em simultâneo em todo o país, por isso delegava esse poder a alguns sacerdotes, certamente o primeiro sacerdote de cada templo, que, em seu nome, realizavam diariamente o culto de Maat. Nos relevos, contudo, só o rei aparece a celebrá-los. Não é de confundir com os "servidores de maat" cujas funçōes estavam mais ligadas ao funcionalismo, onde desempenhavam atribuições judiciais, devendo contudo encomendar-se à deusa antes de julgar (Cfr. E. CASTEL RONDA, Los Sacerdotes en el Antiguo Egipto, Madrid: Alderabán Ediciones, 1999, pp. 238-239; cfr. L. M. ARAÚJO, O Clero do Deus Amon no Antigo Egipto, Lisboa: Edições Cosmos, 1999, p. 55).

(15) P. A. CLAYTON, Chronicle of the Pharaohs, pp. 70-71; R. B. PARKINSON, The Tale of Sinuhe and Other Ancient Egyptian Poems (1940-1640 B. C.), Oxford: University Press, 1997, p. 77; G. LEFEBVRE, Romans et Contes Égyptiens de l'époque pharaonique, Paris: Libr. J. Maisonneuve, 1988, p. 52.

(16) Cfr. G. LefEBVRE, Romans et Contes Égyptiens de l'époque pharaonique, p. 42.

(17) Cfr. T. F. CANHÃO, "O meu caminho é bom". O Conto do Camponês Eloquente. Texto hieroglífico, transliteração, tradução comentada e análise de uma fonte documental, pp. 174-176.

(18) J. ASSMANN, Maât, l'Egypte pharaonique et l'idée de justice sociale, Paris: Éditions La Maison de Vie, 1999, pp. 89-92.

(19) Idem, pp. 92-93.

(20) Idem, pp. 101-107.

(21) Foi certamente a interiorização deste princípio que levou a que nos nomes de coroação alguns reis passassem a atribuir a Ré a posse de Maat. Logo na XII dinastia aparece Amenemhat III com Nimaatré $(n(y)$-m; tt-r $)$, "Aquele que pertence à justiça de Ré", mas na XVIII dinastia temos bastante expressivos Hatchepsut com Maatkaré ( $m 3 \tau t-k 3-r)$, "Maat é o ka de Ré", Amen-hotep III com Nebmaatré (nb-m3rt-r), "Ré é o senhor de Maat" ou, já na XIX dinastia, Seti I com Menmaatré (mn-m3t-r) "Ré é estável em Maat", entre outros. Por seu lado, os nomes de Hórus de Ouro, depois de Tutmés III, passaram a considerar maat como regra de governação passando a intitularem-se "soberanos de Maat" (M.-A. BONHĖME e A. FORGEAU, Pharaon. Les Secrets du Pouvoir, pp. 133-134; P. A. CLAYTON, Chronicle of the Pharaohs, pp. 84, 104, 112 e 140).

(22) Cfr. T. F. CANHÃO, "O meu caminho é bom". O Conto do Camponês Eloquente. Texto hieroglífico, transliteração, tradução comentada e análise de uma fonte documental, pp. 164-166.

(23) J. ASSMANN, Maât, l'Egypte pharaonique et l'idée de justice sociale, pp. 108-113.

(24) M.-A. BONHĖme e A. FORgEAU, Pharaon. Les Secrets du Pouvoir, p. 134.

(25) E. HORNUNG, Les Dieux de l'Égypt. L'Un et le Multiple, Paris: Flammarion, 1992, p. 196.

(26) E. HORNUNG, L'Esprit du Temps des Pharaons, Paris: Philippe Leband Éditeur, Éditions du Félin, 1996, p. 132.

(27) J. ASSMANN, Maât, l'Egypte pharaonique et lidée de justice sociale, pp. 119-123; E. HORNUNG, Les Dieux de l'Égypt, pp. 194-197. Para além disto, os deuses satisfaziam-se, normalmente, com sacrifícios e oferendas funerárias.

(28) M.-A. BONHĖME e A. FORGEAU, Pharaon. Les Secrets du Pouvoir, pp. 140-144. 
(29) R. H. WILKINSON, The Complete Temples of Ancient Egypt, Londres: Thames and Hudson, 1994, pp.155 e 163; J. BAINES e J. MÁLEK, Egipto. Deuses, templos e faraós, Lisboa, Círculo de Leitores, 1991, pp. 91-92. Note-se, que não obstante Shaw e Nicholson afirmarem que "apesar da figura de Maat ser largamente representada em templos de outras divindades, somente alguns templos dedicados à própria deusa sobreviveram, incluindo a pequena estrutura no recinto de Montu em Karnak", não apresentam qualquer outro exemplo (I. SHAW e P. NICHOLSON, British Museum Dictionary of Ancient Egypt, Londres: British Museum Press, 1995, p. 166).

(30) L. M. ARAÚJO, (dir.), Dicionário do Antigo Egipto, Lisboa: Editorial Caminho, 2001, p. 535, col. dir.

(31) M.-A. Bonhème e A. FORGEAU, Pharaon. Les Secrets du Pouvoir, p. 189.

(32) A palavra homem dizia-se $r m t$, provável derivação de lágrimas ( $r m y t$ ), uma vez que teriam sido criados a partir das lágrimas de Hórus (Idem, p. 194).

(33) Idem, p. 206.

(34) Esta função de combatente era também desenvolvida pelo rei na Duat, embora os inimigos sejam agora diferentes: uns são os próprios homens que, indevidamente o querem acompanhar num destino que é só seu; outro é o próprio céu onde o faraó deseja entrar, mas que é necessário forçar por se encontrar fechado; outros serão as tempestades, os tornados e o granizo provocados no mundo dos deuses pela sua difícil partida da terra (Idem, p. 201).

(35) Embora aqui surja na sua versão deificada, iseft significa literalmente: errado, mentira e/ou injustiça (R. O. FAULKNER, A Concise Dictionary of Middle Egyptian, Oxford: Griffith Institute, Ashmolean Museum, 1996, p. 31).

(36) J. ASSMANN, Maât, l'Egypte pharaonique et l'idée de justice sociale, pp. 128-138.

(37) Idem, p. 138.

(38) Idem, ibidem.

(39) Idem, p. 140.

(40) Idem, ibidem.

(41) A este propósito refira-se que Lichtheim inclui numa das suas obras um capítulo onde, sob a forma de glossário, apresenta um Índex Anotado do Vocabulário Moral Egípcio (M. LICHTHEIM, Maat in Egyptian Autobiographies and Related Studies, Fribourg/Göttingen, Biblical Institute of the University of Fribourg, Fribourg: University Press of Fribourg, Vandenhoeck and Ruprecht, OBO 155, 1997, pp. 145-153).

(42) E. TEETER, The Presentation of Maât. Ritual and Legitimacy in Ancient Egypt, SAOC 57, Chicago: The Oriental Institute of the University of Chicago, 1997, p. 2.

(43) Jaques Benigne Bossuet (1627-1704), preceptor de Luís XV e depois bispo, foi um dos maiores teóricos do absolutismo, desenvolvendo e fundamentando a origem divina do poder real na obra A Política Baseada nas Próprias Palavras da Sagrada Escritura, publicada postumamente em 1709 (Grande Enciclopédia Portuguesa e Brasileira, Lisboa/Rio de Janeiro: Editorial Enciclopédia, [s. d.], vol. 4, p. 959, col. dir.; M. PRÉLOT, As Doutrinas Políticas, Lisboa: Editorial Presença, 1974, vol. IV, pp. 213-234).

(44) Nenhum dos três fragmentos deste conto apresenta o final da narrativa, mas o seu enredo tem levantado acesa discussão sobre quem poderia ser a pessoa que gozava dos favores amorosos do rei. Aparentemente poderia ser o próprio general Sisené, a casa de 
quem o rei se dirigia furtivamente pela calada da noite, até porque se sabe que, no Egipto antigo, "outras fontes mostram que a homossexualidade era vista como uma aberração do padrão ideal de vida familiar, similar ao adultério" (R. B. PARKInson, Voices from Ancient Egypt, an Anthology of Middle Kingdom Writings, Londres: British Museum Press, 1991, pp. 54-56).

(45) As ideias de "monarquia divina" e "rei-deus" foram criadas nos finais do século XIX com um sentido universal que nunca tiveram, uma vez que foram criadas fundamentalmente com exemplos africanos. Aliás, a historiografia ocidental considerou até há bem pouco tempo o Egipto Antigo como uma cultura do Próximo Oriente, alheando-se quase por completo da sua localização geográfica e das implicações culturais daí provenientes. Cervello Autuori afirma num interessante artigo: "Como é evidente que os termos "realeza" e "divino" são conotados ao excesso nas nossas linguas, e não podem ser utilizados sem serem definidos, é conveniente precisar desde já o sentido exacto que the atribuímos. A nossa palavra "rei" remete necessariamente para uma forma de poder político-militar, enquanto que o rei ao qual nos referimos não é necessariamente dotado destas prerrogativas e pode ser um personagem que dispõe apenas de funções exclusivamente cósmico-rituais. Nós conservaremos contudo este termo porque se trata, em todo o caso, de um personagem único, centro da vida da sua comunidade, e que pertence necessariamente a uma linhagem marcada de maneira especial, quer dizer, que se trata de um descendente legítimo de determinado antepassado fundador, directamente ligado aos deuses ou às forças cósmicas (é mesmo o princípio da "legitimidade dinástica"). Quanto ao termo "deus", remete na nossa cultura a conceitos como criação e omnipotência. Todavia, o rei-deus africano não é nunca um ser omnipotente nem criador. Bem pelo contrário, a sua "divindade" emana da sua identificação com um deus-vítima sacrificial que, pela sua morte, facilita a ordem e expia o caos. O rei é antes do mais um corpo-fetiche depositário de poder cósmico benéfico, - centro dinâmico do universo, o ser no qual converge o cósmico e o social, um integrador universal; e é por isso que falamos da sua causalidade pessoal. É estritamente como fetiche-vítima sacrificial que é preciso entender a palavra "deus" neste contexto. Ao carácter eminentemente cósmico e ritual do rei divino africano pode eventualmente ser acrescentado um poder político-militar mais ou menos importante numa organização social pré-estatal ou plenamente estatal" (J. CERVELLO AUTUORI, "Monarchie pharaonique et royautés divines africaines", em Cahiers Caribéens d'Egyptologie (2). La Maât dans tous ses Etats, Martinique: Editions Tyanaba, Février/Mars, 2001, pp. 28-30).

(46) M.-A. BONHĖME e A. FORgEAU, Pharaon. Les Secrets du Pouvoir, p. 319. 